\title{
Effect of Leverage on Profitability and Share Return with
}

\section{Intervening Asset Growth}

\section{Pengaruh Leverage terhadap Profitabilitas dan Return Saham dengan Intervening Asset Growth}

\begin{tabular}{l}
\hline Author \\
\hline Akhmad Syarifudin, SE., MSi. \\
Universitas Putra Bangsa \\
Kebumen- Jawa Tengah \\
Akhmadsyartifudin89@gmail.com
\end{tabular}

\section{Duconomics Sci-meet}

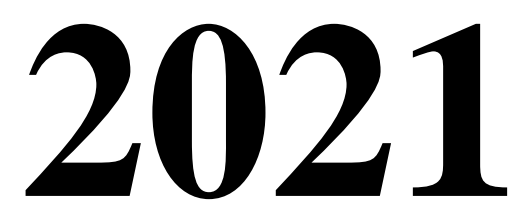

VOLUME 1

JULI

Page

\section{3-251}

DOI

10.37010/duconomics.v1.5444

Corresponding Author

akhmadsyarifudin89@gmail.com

Hp. 0818257996

\begin{abstract}
Fundamental factor analysis is important to determine the company's performance. The purpose of this study is to determine the effect of leverage on profitability \& stock prices through Asset Growth. The population of 664 issuers used 300 purposive samples covering all sectors on the 2011-2019 $B E I$. The research method uses SEM-Smart PLS path analysis. The results in group I (DAR <50\%) DAR had a positive effect on $A G$; negative to ROA; and does not affect ROE; Meanwhile, $A G$ affects $R O E \& P B V$. The result of an indirect relationship AG mediates DAR to RS through ROE, but AG does not mediate DAR to RS through PBV. Shows an increase in debt increases asset growth and dividends, and if the increase in asset growth without increasing debt will increase dividends and stock prices. The results in group II

(DAR>50\%) DAR had a negative effect on AG\&ROA, but did not affect

$R O E$. While AG affects $P B V$, but does not affect ROE. The result of an indirect relationship AG mediates DAR to $R S$ through $P B V$, but AG does not

mediate DAR to RS through ROE. It shows that an increase in debt will

reduce asset growth but will not affect dividends and vice versa, while an increase in asset growth will increase stock prices. This finding proves that the optimal capital structure is effective in improving company performance

on the Indonesia Stock Exchange. Companies that have low debt and

experience asset growth tend to produce high profitability and their share
\end{abstract} prices increase.

Keywords

Leverage, Asset Growth, ROE, PBV, Stock Return

Abstrak

Analisis faktor fundamental penting untuk mengetahui kinerja perusahaan. Tujuan penelitian untuk mengetahui pengaruh leverage terhadap profitabilitas\&harga saham melalui Asset Growth. Populasi 664 emiten digunakan 300 sampel purposive meliputi seluruh sektor di BEI 2011-2019. Metode penelitian menggunakan analisis jalur SEM-Smart PLS. Hasildigroup I(DAR $<50 \%)$ DAR berpengaruh positif terhadap AG; negatif terhadap ROA; dan tidak mempengaruhi ROE; Sedangkan AG mempengaruhi ROE\&PBV. Hasil hubungan tak langsung AG memediasi DAR terhadap RS melalui ROE, tetapi AG tidak memediasi DAR terhadap RS melalui PBV. Menunjukan kenaikan hutang meningkatkan asset growth dan deviden, dan jika kenaikan asset growth tanpa menambah hutang akan meningkatkan deviden dan harga saham.

Hasildigroup II(DAR $\geq 50 \%$ ) DAR berpengaruh negatif terhadap AG\&ROA, tetapi tidak mempengaruhi ROE. Sedangkan AG mempengaruhi PBV, tapi tidak mempengaruhi ROE. Hasil hubungan tak langsung AG memediasi DAR terhadap RS melalui PBV, tetapi AG tidak memediasi

DAR terhadap RS melalui ROE. Menunjukan kenaikan hutang akan menurunkan asset growth tetapi tidak mempengaruhi deviden dan sebaliknya, sedangkan kenaikan asset growth akan meningkatkan harga saham.

Temuan ini membuktikan struktur modal yang optimal efektif meningkatkan kinerja perusahaan di Bursa Efek Indonesia. Perusahaan.yang memiliki hutang rendah dan mengalami pertumbuhan aset cenderung menghasilkan profitabilitas tinggi dan harga sahamnya meningkat.

\section{Kata kunci}

Leverage, Asset Growth, ROE, PBV, Return saham 


\section{PENDAHULUAN}

Setiap perusahaan ingin berkembang dan memberi kemakmuran kepada pemilik maupun manfaat bagi stakeholder lainya. Pada awal operasinya perusahaan selalu optimis memasuki kancah kompetisi bisnis. Munculnya revolusi industri 4.0 yang mengarah pada kemudahan transfer data dan otomatisasi mampu menekan biaya operasional. Biaya transportasi, komunikasi dan beban lainya terpangkas signifikan sehingga logistik dan rantai suplai pasokan global semakin hemat dan kompetitif. Penggunaan inovasi teknologi ini menawarkan efisiensi produksi dan pemasaran yang memberikan keuntungan bagi konsumen dalam jangka panjang. Perkembangan ini merupakan peluang dan tantangan bagi perusahaan untuk tetap survive ditengah pesatnya kemajuan teknologi.

Platform bisnis baru dengan layanan berbasis digital sedang berkembang pesat, sedangkan pola bisnis konvensional mulai tertekan. Perusahaan Blue Bird yang memiliki 29.000 armada transport pendapatanya menurun hingga 70\% (kompas, 2020). Perusahaan plat merah PT Krakatau Steel juga mengalami kerugian secara beruntun yaer on yaer (yoy). Perusahaan yang kurang adaptif terhadap resiko teknik, resiko finansial, maupun resiko pemasaran sangat rentan gagal. Kondisi tersebut menjadi warning bagi manajemen untuk melakukan perbaikan secara terus menerus (continuous improvement) dalam menjaga dan meningkatkan performa perusahaan. Untuk itu diperlukan strategi berlian agar perusahaan tetap survive dalam persaingan bisnis global.

Penerapan strategi perusahaan pada praktiknya sering terkendala kesiapan modal. Keterbatasan akses sumberdaya keuangan menjadi krusial dalam mencari dan menentukan pilihan solusi. Suntikan modal dari pendiri hanya bersifat sementara, karena kekuatan modal pemilik belum tentu mencukupi seiring pengembangan perusahaan. Melakukan penawaran umum perdana (initial public offering) merupakan alternatif sumber pendanaan baru dengan mengubah status menjadi perusahaan go public dan listing di Bursa Efek. Saat ini lebih dari 600 emiten listing di Bursa Efek Indonesia. Selama tahun 2020 BEI mencatat jumlah investor saham, obligasi, maupun reksadana meningkat 56\% menjadi 3,87 juta dengan rata-rata frekuensi perdagangan harian 677.430 transaksi.

Investor usia dibawah 30 tahun mencapai 55\% meskipun investasi kecil 30 triliun dan diatas 60 tahun hanya 4\% dengan investasi Rp 360 triliun. Weston dan Brigham (1993:26-27) mengemukakan faktor yang mempengaruhi harga saham adalah proyeksi laba per lembar saham, tingkat resiko dari proyeksi laba, proporsi utang perusahaan terhadap ekuitas, serta kebijakan pembagian deviden.Fluktuasi perdagangan saham tahun 2020 beberapa emiten harga sahamnya melonjak 100\% lebih yang disinyalir adanya sentimen vaksin covid19.

\begin{tabular}{clrc} 
& Tabel 1.1 Kenaikan Harga Saham Periode 2020 \\
\hline KODE & \multicolumn{1}{c}{ Nama Perseroan Tbk } & $\begin{array}{c}\text { Harga } \\
\text { Saham Rp }\end{array}$ & $\begin{array}{c}\text { Kenaikan } \\
\text { harga saham }\end{array}$ \\
\hline$\underline{\text { CENT }}$ & Centratama Telekomunikasi Ind & 150 & $105,48 \%$ \\
$\underline{\text { KAIM }}$ & Wismilak Inti Makmur & 358 & $113,10 \%$ \\
$\underline{\underline{\text { SAPX }}}$ & Kimia Farma & 3.250 & $160,00 \%$ \\
$\underline{\text { PNSE }}$ & Satria Antaran Prima & 2.200 & $165,06 \%$ \\
$\underline{\underline{\text { PYAFA }}}$ & Pudjiadi \& Sons Estate & 900 & $171,08 \%$ \\
& Indofarma & 3.300 & $279,31 \%$ \\
& Pyridam Farma & 985 & $397,47 \%$
\end{tabular}

Pergerakan harga saham dapat menjadi barometer kekuatan daya tarik perusahaan bagi investor. Tabel diatas menunjukan lonjakan harga saham diatas $100 \%$ dari ekuitasnya. Keuntungan investor dalam jangka pendek (trader) bisa meraih kapital gain tinggi diatas rata- 
rata return on equity. Oleh sebab itu, para trader dalam transaski perdagangan dipasar modal cenderung mengabaikan kalkulasi deviden yang dinyatakan dalam earning per share (EPS). Pertimbangan investor lebih banyak dipengaruhi oleh ekspektasi kenaikan nilai buku dan harga saham yang akan memberikan keuntungan (return saham).Sejak Januari-5 Feb 2021 rata-rata volume perdagangan harian di Bursa Efek Indonesia 22,90 miliar saham dengan Rata-rata Nilai Transaksi Harian (RNTH) mencapai Rp 20,02 triliun (Investor.co).

Saham adalah selembar kertas yang menyatakan kepemilikan dari sebagian perusahaaan (Bernstein1995:197). Tujuan memasuki pasar modal bukan sekedar akses modal tetapi dapat menciptakan keunggulan kompetitif, meningkatkan going concern dan mengharumkan citra perusahaan (company image) serta menurunkan resiko kredit. Dari pengamatan empiris, hampir semua emiten di BEI mengambil pinjaman sebagai tambahan modal dari pihak eksternal. Proporsi utang dibanding aset (debt to asset ratio) besarnya bervariasi dari yang kecil hingga memiliki (DAR) diatas 50\% (tinggi). Berikut ini gambaran performa finansial pada beberapa perusahaan go public periode 2011-2019.

Tabel 1.2 Kinerja Perusahaan Go public 2011-2018 (Trend meningkat)

\begin{tabular}{ccrrrrrrr}
\hline $\begin{array}{c}\text { Perusahaan } \\
\text { Kode saham }\end{array}$ & Tahun & $\begin{array}{c}\text { Asset } \\
\text { (milyar) }\end{array}$ & $\begin{array}{c}\text {.liabilities } \\
\text { (Milyar) }\end{array}$ & $\begin{array}{c}\text { DER } \\
\text { \% }\end{array}$ & $\begin{array}{c}\text { Deviden } \\
\text { ROE \% }\end{array}$ & Nilai buku & PBV & $\begin{array}{c}\text { Harga saham } \\
\text { Rp }\end{array}$ \\
\hline $\begin{array}{c}\text { HMSP } \\
\text { Consumer good }\end{array}$ & 2011 & 19,330 & 9,027 & 0,9 & 78 & 94 & 16,6 & 1.500 \\
MLBI & 2018 & 46,602 & 11,244 & 0,3 & 38 & 304 & 12,2 & 4.710 \\
Consumer good & 2018 & 1,220 & 690 & 1,3 & 96 & 252 & 14,3 & 3590 \\
MKPI & 2011 & 2,889 & 1,445 & 1,5 & 105 & 554 & 28,9 & 16000 \\
Property & 2018 & 7,008 & 1,776 & 0,3 & 19 & 5517 & 4,1 & 22.500 \\
\hline
\end{tabular}

Sampel korporasi diatas mendeskripsikan perubahan faktor fundamental memiliki efek kinerja keuangan yang berbeda-beda dalam jangka waktu tertentu. HMSP dan MKPI memiliki pola yang hampir sama dimana rasio hutangnya (DER) menurun makin kecil, asetnya meningkat, profitabilitasnya (deviden) justru menurun tetapi harga sahamnya meningkat. Pada MLBI rasio DER naik makin tinggi, asetnya naik, deviden dan harga sahamnya juga naik tinggi. Hal tersebut menunjukan perubahan rasio hutang dan aset berdampak pada profitabilitas harga saham. Pada periode tahun 2020 terdapat fenomena covid19 yang memiliki dampak cukup signifikan terhadap perubahan faktor fundamental.

Tabel 1.3 Kinerja Perusahaan Go public 2011-2018 (trend menurun)

\begin{tabular}{ccrrrrrrr}
\hline $\begin{array}{c}\text { Perusahaan } \\
\text { Kode saham }\end{array}$ & kode & $\begin{array}{c}\text { Aset } \\
\text { (Milyar) }\end{array}$ & $\begin{array}{c}\text { Hutang } \\
\text { (Milyar) }\end{array}$ & $\begin{array}{c}\text { DER } \\
\text { \% }\end{array}$ & $\begin{array}{c}\text { Deviden } \\
\text { ROE }\end{array}$ & $\begin{array}{c}\text { Nilai } \\
\text { buku }\end{array}$ & PBV & $\begin{array}{c}\text { Harga } \\
\text { Saham Rp }\end{array}$ \\
\hline HRUM & 2011 & 4,643 & 1,087 & 0,3 & $42 \%$ & 1317 & 5,2 & 6.850 \\
Mining & 2018 & 5,026 & 1,151 & 0,3 & $11 \%$ & 1618 & 0,9 & 1.400 \\
KKGI & 2011 & 977 & 320 & 0,5 & $69 \%$ & 657 & 9,8 & 6.000 \\
Mining & 2018 & 1,668 & 442 & 0,4 & $1 \%$ & 245 & 1,4 & 354 \\
LION & 2011 & 396 & 64 & 0,2 & $17 \%$ & 5806 & 0,9 & 5.250 \\
Basic industry & 2018 & 696 & 221 & 0,5 & $3 \%$ & 914 & 0,7 & 680 \\
\hline
\end{tabular}

Tabel 1.3 menunjukan HRUM hutangnya stabil, aset bertumbuh, namun profitabilitas dan harga saham menurun. Pada KKGI dan LION rasio DER berubah tetapi profitabilitas dan 


\section{6}

Merdeka Belajar dan Tantangan Ekonomi dalam Menyongsong Era Society 5.0 harga sahamnya menurun. Sejalan dengan temuan Singh, A. \& Hamid, J (1992), bahwa perusahaan-perusahaan di negara berkembang lebih mengutamakan untuk menerbitkan ekuitas daripada mengakses dana hutang untuk mendanai perusahaanya. Beberapa sampel perusahaan tersebut mengisyaratkan derita kerugian bagi investor selaku pemegang saham.

Tabel 1.4 Kinerja Perusahaan Go public 2011-2018 (fluktuatif)

\begin{tabular}{ccccccccc}
\hline $\begin{array}{c}\text { Perusahaan } \\
\text { Kode saham }\end{array}$ & kode & $\begin{array}{c}\text { Aset } \\
\text { (Milyar) }\end{array}$ & $\begin{array}{c}\text { Hutang } \\
\text { (Milyar) }\end{array}$ & $\begin{array}{c}\text { DER } \\
\text { BUMI }\end{array} 2011$ & 64.201 & 56,146 & 7,0 & \multicolumn{2}{c}{$\begin{array}{c}\text { Deviden } \\
\text { ROE }\end{array}$} & $\begin{array}{c}\text { Nilai } \\
\text { buku }\end{array}$ & PBV & $\begin{array}{c}\text { Harga pasar } \\
\text { 2011\&2019 }\end{array}$ \\
\hline Mining & 2018 & 40.255 & 49,281 & $-17,2$ & $-112 \%$ & -44 & $-2,4$ & 103 \\
PLIN & 2011 & 4.515 & 2.232 & 1,0 & $4 \%$ & 657 & 2,4 & 1550 \\
Properti, real est & 2018 & 4.930 & 3,811 & 3,4 & $18 \%$ & 315 & 9,1 & 2780 \\
BRMS & 2011 & 17.081 & 3.339 & 0,2 & $\%$ & 537 & 1,0 & 530 \\
Treade, service & 2018 & 13.766 & 2.487 & 0,2 & $\%$ & 181 & 1,1 & 50 \\
\hline
\end{tabular}

Informasi diatas menunjukan nilai buku perusahaan BUMI mengalami perunuruan sejalan dengan turunya harga saham. Nilai buku PLIN juga menurun, tetapi jumlah asetnya mengalami pertumbuhan diikuti dengan kenaikan harga saham dalam jangka panjang dari 1.550 ditahun 2011 menjadi 2.780 ditahun 2018. Hal ini mengindikasikan kenaikan aset memiliki hubungan dengan kenaikan harga saham. Sedangkam pada BRMS jumlah hutang menurun tetapi rasio DER tidak berubah dan dan harga sahamnya merosot. Beberapa kajian empiris tersebut menunjukan jika struktur modal, pertumbuhan asert dan nilai buku emiten memiliki efek yang berbeda-beda terhadap profitabilitas dan harga sahamnya.

Penananam investasi di pasar modal merupakan kegiatan penempatan dana atau sejumlah aset pada satu perusahaan atau lebih untuk periode tertentu dengan harapan dapat meraih keuntungan (return saham) atas nilai yang diinvestasikan. Tabel diatas menunjukan fluktuasi harga saham yang cenderung meningkat. Namun jika menghitung nilai investasi dalam jangka panjang, nilai buku (book value) pada beberapa emiten meningkat signifikan. Beberap perusahaan bahkan harga sahamnya naik mencapai 500\% lebih dalam 7 tahun, meskipun pada sebagian emiten lainya justru terkoreksi. Artinya, keuntungan investor tidak hanya mengandalkan ekspektasi deviden, namun kenaikan harga sahamnya justru sangat diharapkan.Tujuan utama perusahaan go public yaitu meningkatkan kemakmuran pemegang saham melalui peningkatan nilai perusahaan (Salvator ,2005).

Saham merupakan suatu sekuritas yang memiliki klaim terhadap pendapatan dan aset sebuah perusahaan. Sekuritas sendiri dapat diartikan sebagai klaim atas pendapatan masa depan seorang peminjam yang dijual oleh peminjam kepada yang meminjamkan yang sering disebut instrumen keuangan (Miskhin, 2001:4). Teori Trade-off mengemukakan bahwa kebijakan pendanaan dalam menentukan bauran antara hutang dan ekuitas (struktur modal) bertujuan untuk mengoptimalkan nilai perusahaan (value of the firm). Artinya, bila komposisi sumber modal telah melampaui target struktur modal optimalnya, maka setiap tambahan hutang akan menurunkan nilai perusahaan. Nilai perusahaan merupakan nilai pasar atas surat berharga utang dan ekuitas (saham) perusahaan yang beredar (Keown,2000).

Dari pengamatan terhadap laporan keuangan 2011-2019 di BEI, hampir seluruh emiten mengalami perubahan khususnya pada leverage, aset, profitabilitas dan harga saham. Berdasarkan teori struktur modal, perubahan faktor fundamental tersebut memiliki hubungan timbal balik terhadap kinerja perusahaan yang dapat mempengaruhi deviden, nilai buku dan

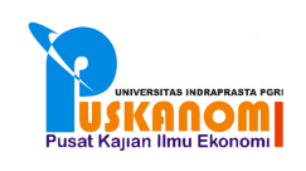


harga saham. Oleh karenanya, investor sangat membutuhkan informasi penting dari faktor fundamental sebagai bahan pertimbangan keputusan bisnis. Penggunaan dana pinjaman (loan) berpotensi menambah keuntungan perusahaan karena bunga utang bisa mengurangi beban pajak. Konsekuensinya, kebijakan utang (financial policy) menimbulkan disiplin baru bagi manajemen untuk membayar kewajiban. Selain itu kerugian penggunaan hutang juga berhubungan dengan agency cost dan biaya kepailitan.

Myers (1984) dalam pecking ordertheory menjelaskan perusahaan dengan tingkat profitabilitas tinggi akan memiliki kecukupan sumber dana internal, sehingga penggunaan utangnya rendah. Sedangkan Modigliani dan Miller(1958) dengan berbagai asumsi didalam teorinya menjelaskan nilai perusahaan tidak dipengaruhi struktur modal. Pandangan teori MM ini berbeda dengan teori trade-off (2001),bahwa perusahaan akan berhutang sampai pada tingkat tertentu, dimana penghematan pajak (tax shields) dari tambahan hutang sama dengan biaya kesulitan finansial. Teori ini sejalan dengan David Durand (1952) dengan pendekatan tradisional, yang mengamsusikan perubahan struktur modal yang optimal dan peningkatan nilai total perusahaan melalui penggunaan hutang.

Penelitian Setyawan \& Syaftina (2013) menyatakan ada enam rasio keuangan (QR, DER, ROE, ITO, PBV, dan PER) yang dapat meningkatkan kinerja keuangan dan nilai rasio penilaian pasar yang paling dominan meningkatkan kinerja pada emiten LQ-45. Sedangkan Raisa Fitri (2017) menunjukan kebijakan dividen (DPR), leverage (DER), profitabilitas (ROE) secara parsial maupun simultan tidak berpengaruh terhadap return saham. Hasil yang berbeda ditunjukan Aziz dan Hartono (2017) bahwa DAR berpengaruh negatif terhadap kinerja, LTDER dan DER keduanya sama-sama tidak mempengaruhi kinjer keuangan. Hasil ini sejalan dengan temuan Rajhkumar P.(2014) bahwa Leverage berpengaruh negatif terhadap kinerja keuangan John Keels holdings Plc Sri Lanka.

Panelitian Wasfi dan Haneen (2016), hasilnya struktur modal berpengaruh negatif terhadap return saham, sedangkan likuiditas dan pengembalian saham berpengaruh positif terhadap return saham di Amman Stock Exchange. Matar dan Eneizan (2018), mengungkapkan bahwa variabel likuiditas, profitabilitas dan pendapatan berhubungan positif dengan pengembalian. Dari hasil regresinya menunjukkan bahwa semua variabel berpengaruh signifikan terhadap kinerja perusahaan sektor industri 2005-2015 di Amman Stock Exchange Jordania. Hasil ini sejalan denganSchutte, Maarten (2018) pada emiten Eropa periode 20092017, bahwa leverage berpengaruh negatif terhadap kinerja keuangan ROA, ROE, Tobin's Q dan Stock Return. Hasil ini menunjukkan bahwa kinerja keuangan meningkat ketika perusahaan beroperasi dengan rasio DER yang lebih rendah.

Berdasarkan latar belakang, analisis faktor fundamental penting untuk menilai kinerja keuangan, prospek, resiko, dan kewajaran harga saham. Hal tersebut menarik minat penulis melakukan penelitian ini, yaitu dengan menguji pengaruh leverage dan pertumbuhan aset terhadap profitabilitas dan return saham. Penentuan faktor fundamental dilakukan untuk menyusun kerangka penelitian agar mendapatkan hasil sesuai tujuan. Populasi dan sampel meliputi seluruh sektor di BEI yang dibagi menjadi dua group dengan tingkat leverage yang berbeda. Hasil penelitian diharapkan dapat mengidentifikasi karakteristik fundamental emiten yang prospektif dan dapat mendeteksi dari sisi mana potensi return saham akan diperoleh. Hasil penelitian diharapkan bermanfaat bagi manajemen, investor dan stakeholder lainya untuk menentukan arah kebijakan dan pertimbangan keputusan bisnis.

\section{TINJAUAN PUSTAKA}

\section{Teori Trade-Off}


Merdeka Belajar dan Tantangan Ekonomi dalam Menyongsong Era Society 5.0

Myers (2001) mengungkapkan bahwa perusahaan akan menggunakan hutang sampai tingkatan tertentu (trade off) selama masih memberikan keuntungan dari sisi efisiensi pemajakan (tax shileds) dari nilai hutangnya sama dengan beban kesulitan finansial. Penentuan struktur modal optimal pada teori trade-off telah menambahkan beberapa unsur seperti beban pajak, agency cost dan biaya kebangkrutan namun tetap mempertahankan asumsi efisiensi pasar dan symmetric information sebagai kesimbangan dan manfaat hutang. Dalam praktiknya, penggunaan utang memiliki batasan tertentu sehingga tidak dapat digunakan yang sebesarbesarnya akibat dari timbulnya konsekuensi beban hutang.

Beban kesulitan keuangan adalah biaya kebangkrutan (bankruptcy costs) atau reorganization dan kenaikan biaya keagenan (agency costs) akibat menurunya kredibilitas perusahaan. Toeri ini berasumsi bahwa perusahaan memiliki tingkat utang yang optimal, sehingga ketika utangnya terlalu rendah (under levered) ataupun terlalu tinggi (overlevered) akan berupaya untuk menyesuaikan utang aktualnya menuju titik optimal. Esensi trade-off theory dalam leverage adalah keseimbangkan pengorbanan dan manfaat yang timbul akibat penggunaan utang. Selagi utang masih memberi manfaat lebih besar, maka tambahan utang masih diperbolehkan. Namun jika biaya utang sudah lebih besar, maka penambahan utang harus dihentikan.

\section{Teori Struktur Modal}

Teori struktur modal mulai dikembangkan David Durand pada tahun 1952 menggunakan tiga pendekatan, yaitu: pendekatan tradisional, laba operasi dan laba bersih (net profit approach) dengan asumsi perusahaan tidak terbebani pajak.

a.Pendekatan laba bersih, mengasumsikan biaya modal saham (cost of equity) dan biaya utang (cost of debt) bersifat konstan. Artinya penggunaan utang yang semakin besar akan memperkecil biaya modal rata-rata tertimbangnya, sehingga nilai perusahaan akan meningkat. Implikasi teori ini, perusahaan cenderung menggunakan utang sampai pada titik tertentu untuk meningkatkan nilai perusahaan. Pada awalnya nilai perushaaan tidak naik, kemudian nilainya akan mengalami peningkatan.

b. Pendekatan laba operasi, berasumsi bahwa reaksi investor berbeda-beda terhadap perusahaan yang memiliki hutang cukup besar. Pada pendekatan ini cost of debt dan rata-rata biaya modal tetap sehingga cost of equity meningkat sejalan dengan kenaikan hutang dan resikonya. Semakin tinggi utang perusahaan dipandang investor akan meningkatkan konsekuensi biaya modal selain resiko. Artinya jika perusahaan menggunakan utang yang semakin besar, maka bagian laba pemilik modal (deviden) cenderung menurun.

c. Pendekatan tradisional, mengungkapkan adanya struktur modal yang optimal, artinya perubahan struktur modal memiliki pengaruh terhadap peningkatan nilai total perusahaan yang optimal melalui penggunaan hutang (leverage). Pendekatan ini memberikan biaya modal (cost of debt) keseluruhan yang terendah dan harga saham tertinggi. Penyebabnya adalah perubahan tingkat kapitalisasi perusahaan setelah perusahaaan merubah struktur modalnya pada batas tertentu akibat dari perubahan resiko.

\section{Kinerja Keuangan}

Perubahan kondisi ekonomi perusahaan tercermin dari performa perusahaan yang dapat dilihat dari rasio-rasio finansial. Perusahaan yang berkembang akan mendorong pertumbuhan seperti pertumbuhan aset, revenue, net income,leverage (hutang), profitabilitas, earning per share (EPS), price to book value (PBV) maupun market value. Perkembangan rasio keuangan ini cukup penting sebagai indikator kinerja, mengingat unsur persepsi resiko investasi dapat dipengaruhi oleh berbagai faktor baik internal maupun eksternal. 


\section{Struktur Modal}

Struktur modal didefinisikan sebagai kumpulan dana yang dapat digunakan dan dialokasikan oleh perusahaan dimana dana tersebut diperoleh dari hutang jangka panjang dan modal sendiri (Gitman, 2006). Menurut Fahmi (2014), struktur modal merupakan gambaran dari bentuk proporsi finansial yaitu antara modal yang dimiliki yang bersumber dari hutang jangka panjang (long-term liabilities) dan modal sendiri (shareholders equity). Dari beberapa definisi dapat disimpulkan bahwa struktur modal merupakan proporsi antara modal sendiri dengan total hutang yang digunakan untuk memenuhi kebutuhan dana operasional.

\section{Rasio Solvabilitas (Leverage)}

Leverage merupakan rasio antara jumlah hutang dibanding aset perusahaan. Menurut Sartono (2008) leverage adalah pemanfaatan asset dan sumber pendaan (source of funds) yang minimbulkan beban tetap bagi perusahaan untuk meningkatkan potensi keuntungan (return) para pemilik saham. Solvabilitas adalah rasio untuk mengukur sejauh mana aset perusahaan dibiayai oleh utang (Kasmir, 2010). Rasio ini dapat digunakan untuk mengukur kemampuan perusahaan membayar total kewajibanya jika perushaan dilikuidasi. Perusahaan yang hutangnya melebihi $D A R>50 \%$ dianggap memiliki tingkat leverage tinggi.

\section{Pertumbuhan Aset}

Aset merupakan aktiva perusahaan untuk menunjang kegiatan operasional. Perkembangan aset tercatat di neraca perusahaan untuk meningkatkan nilai dan penghasilan. Besarnya aset dapat dipandang sebagai potensi perolehan dimasa depan misalnya untuk memperoleh arus kas, efisiensi, dan meningkatkan penjualan. Nilai total aset dapat menjadi ukuran besar kecilnya perusahaan (firm size) yang dapat meningkatkan kepercayaan publik. Semakin besar aset makin besar harapan penghasilan, dan sebaliknya jika asetnya kecil keuntunganya juga relatif kecil. Namun, disisi lain aset yang terlalu besar bisa dianggap menghambat laju perusahaan karena beban depresiasi lebih tinggi. Kondisi tersebut dapat memiliki efek terhadap pergerakan saham. Oleh karenanya pertumbuhan aset perlu pengendalian agar pertumbuhanya optimal dalam menghasilkan keuntungan.

\section{Profitabilitas}

Profitabilitas merupakan rasio untuk menilai kemampuan manajemen dalam menghasilkan keuntungan usaha. Menurut Kasmir (2008), profitabilitas merupakan gambaran dari kinerja manajemen dalam mengelola perusahaan. Profitabilitas adalah kemampuan perusahaan memperoleh laba dalam hubungannya dengan penjualan, total aktiva maupun modal sendiri (Sartono,2001). Menurut Weston dan Bringham (1997) profitabilitas merupakan ukuran efektifitas manajemen secara keseluruhan yang ditujukan oleh besar kecilnya tingkat keuntungan yang diperoleh dalam hubungannya dengan penjualan atau investasi.Dalam penelian ini profitabilitas di proxy-kan dengan Return on Aset (ROA) dan return on equity (ROE).

\section{Price to Book Value $(P B V)$}

Nilaiperusahaan sangat penting karena dengan nilai perusahaan yang tinggi akan diikuti oleh tingginya kemakmuran pemegang saham (Brigham and Gapensi,1996). Harga pasar nilai buku (PBV) merupakan salahsatu indikator fundamental suatu saham yang menunjukkan kemamupuan manajemen dalam menciptakan nilai perusahaan yang relatif atas jumlah investasi modal. Rasio PBV dapat menjadi ukuran berapa besar penghargaan pasar terhadap 


\section{0}

Merdeka Belajar dan Tantangan Ekonomi dalam Menyongsong Era Society 5.0 nilai buku saham. Rumus menghitung valuasi saham (PBV) yaitu market per share dibagi book value. Saham emiten yang memiliki PBV diatas 1 dianggap overvalue sedangkan yang dibawah 1 berarti undervalue.

\section{Return Saham}

Return saham adalah keuntungan yang didapatkan oleh pemegang saham. Sumber keuntungan investasi pada sekuritas saham adalah dari deviden ditambah dengan selisih kenaikan harga saat pembelian dan harga jual saham (capital gain). Rumus untuk menghitung Return Saham adalah deviden ditambah capital gain.

\section{Model penelitian}

Penelitian ini akan menguji hubungan pengaruh leverage (hutang) dan pertumbuhan aset terhadap profitabilitas dan return saham. Kriteria sampel yang digunakan adalah perusahaan go public yang telah beroperasi lebih dari 10 tahun. Perushaan akan dibagi menjadi dua yaitu kelompok I untuk DAR $<50 \%$ dan kelompok II untuk DAR $\geq 50 \%$.

\section{Gambar 2.1.Model penelitian}

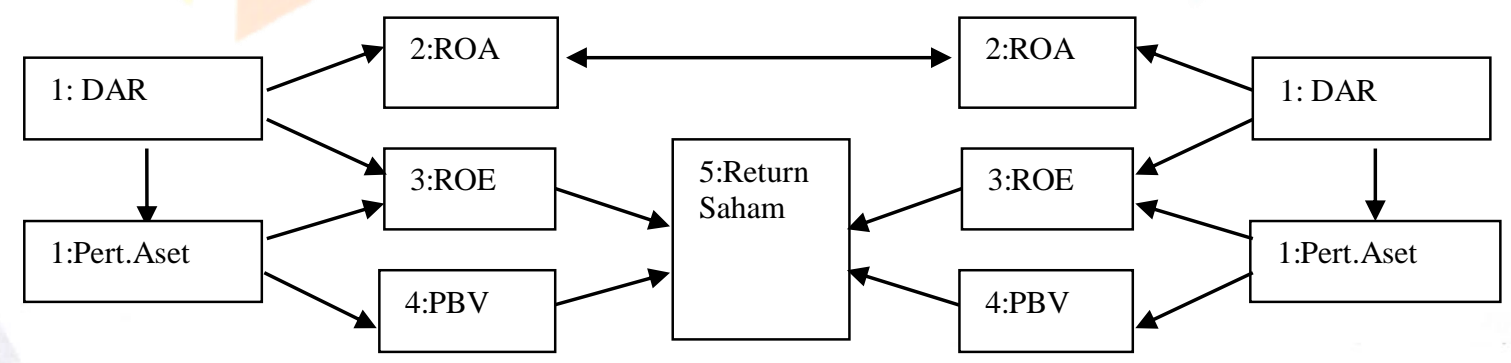

\section{Hiotesis}

Sesuai landasan teori, kerangka pikir dan kajian empiris maka hipotesisnya sebagai berikut:

\begin{tabular}{|c|c|}
\hline Hipotesis kelopok I (DAR < 50\%) & $\begin{array}{c}\text { Hipotesis kelompok II (DAR } \\
>\mathbf{5 0 \%})\end{array}$ \\
\hline A. Direct Effect & A. Direct Effect \\
\hline 1. $\mathrm{DAR} \longrightarrow \mathrm{AG}$ arah positif & 1. $\mathrm{DAR} \rightarrow \mathrm{AG}$ arah negatif \\
\hline 2. $\mathrm{DAR} \longrightarrow \mathrm{ROA}$ arah negatif & 2. $\mathrm{DAR} \rightarrow \mathrm{ROA}$ arah negatif \\
\hline 3. $\mathrm{DAR} \longrightarrow \mathrm{ROE}$ arah positif & 3. $\mathrm{DAR} \longrightarrow \mathrm{ROE}$ arah negatif \\
\hline 4. $\mathrm{AG} \rightarrow \mathrm{ROE}$ arah positif & 4. $\mathrm{AG} \rightarrow \mathrm{ROE}$ arah positif \\
\hline 5. $\mathrm{AG} \rightarrow \mathrm{PBV}$ arah positif & 5. $\mathrm{AG} \rightarrow \mathrm{PBV}$ arah positif \\
\hline 6. $\mathrm{ROE} \rightarrow \mathrm{RS}$ arah positif & 6. $\mathrm{ROE} \rightarrow \mathrm{RS}$ arah positif \\
\hline 7. $\mathrm{PBV} \rightarrow \mathrm{RS}$ arah positif & 7. $\mathrm{PBV} \rightarrow \mathrm{RS}$ arah positif \\
\hline B. Indirect Effect & B. Indirect Effect \\
\hline 1. $\mathrm{DAR} \longrightarrow \mathrm{AG} \rightarrow \mathrm{ROE}$ mediasi positif & 1. $\mathrm{DAR} \longrightarrow \mathrm{AG} \rightarrow \mathrm{ROE}$ mediasi negatif \\
\hline 2. $\mathrm{DAR} \longrightarrow \mathrm{AG} \rightarrow \mathrm{PBV}$ mediasi positif & 2. $\mathrm{DAR} \longrightarrow \mathrm{AG} \longrightarrow \mathrm{PBV}$ mediasi negatif \\
\hline 3. $\mathrm{DAR} \longrightarrow \mathrm{ROE} \longrightarrow \mathrm{RS}$ mediasi positif & 3. $\mathrm{DAR} \longrightarrow \mathrm{ROE} \rightarrow \mathrm{RS}$ mediasi negatif \\
\hline 4. $\mathrm{AG} \rightarrow \mathrm{ROE} \longrightarrow \mathrm{RS}$ mediasi positif & 4. $\mathrm{AG} \rightarrow \mathrm{ROE} \longrightarrow \mathrm{RS}$ mediasi positif \\
\hline $5 \mathrm{AG} \rightarrow \mathrm{PBV} \rightarrow \mathrm{RS}$ mediasi positif & $5 \mathrm{AG} \rightarrow \mathrm{PBV} \rightarrow \mathrm{RS}$ mediasi positif \\
\hline 6. $\mathrm{DAR} \longrightarrow \mathrm{AG} \longrightarrow \mathrm{ROERS} \rightarrow$ mediasi positif & 6. DAR $\longrightarrow \mathrm{AG} \longrightarrow \mathrm{ROERS}$ ediasi negatif \\
\hline 7. $\mathrm{DAR} \longrightarrow \mathrm{AG} \longrightarrow \mathrm{PBV} \longrightarrow \mathrm{RS}$ mediasi positif & 7. $\mathrm{DAR} \longrightarrow \mathrm{AG} \longrightarrow \mathrm{PBV} \longrightarrow \mathrm{RS}$ mediasi negatif \\
\hline
\end{tabular}

\section{METODE}

\section{Sumber Data}

Jenis data yang digunakan adalah data kuantitatif dan kualitatif. Pengumpulan data sekunder dari laporan tahunan perusahaan yang terdaftar di Bursa Efek Indonesia periode 2011-2019. 
Laporan keuangan tersebut diambil dari Indonesian capital market directory (ICMD) yang dipublikasikan melalui laman www.idx.co.id. Populasi terdiri dari 664 Emiten meliputi seluruh sektor, digunakan 300 sampel yang diambil secara purposive. Selain itu juga mengumpulkan literatur pendukung dari berbagai sumber seperti, buku, karya ilmiah dan dokumen lainnya. Teknik pengambilan sampel dengan metode purposive sampling jenis judgement sampling, yaitu pemilihan sampel dengan pertimbangan tertentu sesuai tujuan penelitian atau masalah penelitian yang dikembangkan (Ferdinand, 2006).

\section{Operasionalisasi Variabel}

Dalam penelitian ini terdapat variabel independent atau prediktor, variable mediasi atau intervening, dan variabel dependen atau terikat . Variabel independent atau anteseden yaitu X1 (Debt to Asset Ratio), Variabel intervening meliputi: Y1 (Asset Growth); Y2 (Retrun On Asset); Y3 (Retrurn On Equity); Y4 ( Price Book Value). Dan variabel dependen yaitut Y5 (Return Saham). Pengujian hubungan pengaruh antar variabel dilakukan dengan SEM-Smart PLS3.

\section{Statistik Inferensial}

Metode analisis data untuk statistik inferensial menggunakan analisis jalur (path analysis) dengan bantuan statistik. Menurut Sugiyono (2010) analisis jalur merupakan pengembangan dari analisis regresi, sehingga analisis regresi dapat dikatakan sebagai bentuk khusus dari analisis jalur (regression in special of path analysis). Alasan yang mendasari penggunaan model path analysis dalam penelitian ini adalah:

1. Analisis hubungan antar variabel yang kompleks dan tidak dapat dilakukan dengan analisis regresi berganda sehingga membutuhkan serangkaian persamaan regresi.

2. Pemodelan dikembangkan tanpa menggunakan variabel laten dan variabel indikator.

Penggunaan analisis jalur dalam analisis data penelitian didasarkan pada beberapa asumsi (Sugiyono, 2010:297), yaitu:

a. Hubungan antar variabel yang akan dianalisis berbentuk linier, aditif dan kausal.

b. Variabel-variabel residual tidak memiliki korelasi dengan variabel yang mendahuluinya dan tidak berkorelasi dengan variabel lain.

c. Dalam model hubungan variabel hanya terdapat jalur kausal atau sebab-akibat.

d. Data setiap variabel yang dianalisis adalah data interval dan dari sumber data yang sama.

\section{Analisis Jalur (Path Analysis)}

MenurutGhozali (2016), analisis jalur (path analysis) merupakan perluasan dari regresi linear berganda, yaitu penggunaan analisis regresi untuk menaksir hubungan kausalitas antar variabel yang sudah ditetapkan sebelumnya. Langkah-langkah dalam melakukan analisis jalur dalam penelitian ini adalah sebagai berikut:

1. Uji asumsi klasik:

Uji normalitas, multikoleniaritas, autokorelasi, heteroskedastisitas, dan uji linearitas

2. Menghitung koefisien jalur yang didasarkan pada koefisien korelasi

3. Menghitung koefisien jalur yang didasarkan pada koefisien regresi

4. Uji hipotesis

5. Koefisien Determinasi Total(Q2) 


\section{Teknik Analisis Data Statistik Deskriptif}

Merdeka Belajar dan Tantangan Ekonomi dalam Menyongsong Era Society 5.0

Analisis statistik deskriptif memberi gambaran suatu data yang dilihat dari nilai ratarata (mean), standar deviasi, varian, maksimum, minimum, sum, range, kurtosis, dan kemencengan distribusi (skewness), Ghozali (2009:100).

\section{Uji kecocokan model (Goodness of Fit Index)}

Pengujian Goodness of Fit Index $(G o F)$ dilakukan untuk mengevaluasi performa gabungan antara model struktural (inner model) dan model pengukuran (outer model) dengan rumus perhitungan sebagai berikut :

$$
\mathrm{GoF}=\sqrt{A V E \times R^{2}} \text { Keterangan: AVE (average variance extracted) }
$$

\section{Metode Bootsraping}

Metode bootstrap dikembangkan Efron (1979) sebagai alat bantu untuk mengurangi ketidakandalan terkait dengan kesalahan pemakaian distribusi normal dan penggunaanya. Pada bootstrap dibuat data bayangan (pseudo data ) menggunakan informasi dan sifat-sifat data asli, sehingga data bayangan memiliki karakteristik yang mirip dengan data aslinya. Pada metode bootstrap pengambilan sampel dilakukan dari sampel data (resampling with replacement)

\section{Prosedur Analisis Variabel Intervening}

Pengujian variabel intervening dapat dilakukan dengan sobel test melalui bantuan Sobel Test Calculator untuk melihat indirect effect berdasarkan ketentuan nilai z-value> 1,96 atau pvalue $<\alpha=0.05$. Menurut Ghozali (2016:255), sobel test menginginkan asumsi jumlah sampel besar dan nilai koefisien berdistribusi normal. Pengujian sobel test dapat dilakukan dengan empat tahap yaitu:

1. Melihat koefisien antara variabel independen dan variabel intervening (koefisien A).

2. Melihat koefisien antara variabel intervening dan variabel independen (koefisien B).

3. Melihat standar error dari A.

4. Melihat standar error dari B.

\section{HASIL DAN PEMBAHASAN}

\section{Hasil Deskripsi Kelompok I DAR $<\mathbf{5 0 \%}$}

\section{Gambar 4.1 Hasil Pengujian KoefisienJalur (Path Coefficient)}
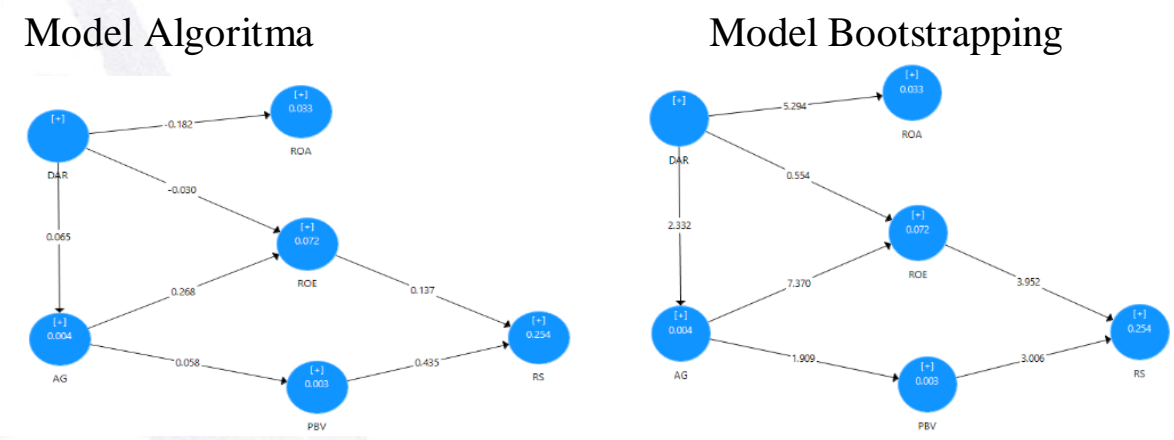

Model algoritma pada gambar 4.1 adalah model SEM dimana yang ditampilkan pada model adalah nilai koefisien SEM. Misalnya 0,065 pada DAR terhadap Asset Growth yang merupakan nilai koefisien SEM.Model algoritma pada gambar 4.2 adalah model SEM dimana 
yang ditampilkan pada model adalah nilai T Statistik SEM. Misalnya 2,332 pada DAR terhadap Asset Growth yang merupakan nilai t statistik SEM.

Tabel 4.1

Koefisien Jalur

Mean, STDEV, T-Values, P-Values

\begin{tabular}{lrrrrrr}
\hline DAR < 50\% & $\begin{array}{l}\text { Sampel } \\
\text { Asli (O) }\end{array}$ & $\begin{array}{l}\text { Rata-rata } \\
\text { Sampel (M) }\end{array}$ & $\begin{array}{l}\text { Standar } \\
\text { Deviasi } \\
\text { (STDEV) }\end{array}$ & $\begin{array}{l}\text { T Statistik } \\
(|\mathrm{O} / \mathrm{STDEV}|)\end{array}$ & $\begin{array}{l}\text { P Values } \\
\text { Analisis hasil olah data } \\
\text { dengan SEM } \\
\text { (Dengan Alfa 5\%) }\end{array}$ \\
\hline DAR -> AG & 0.065 & 0.066 & 0.028 & 2.332 & $\mathbf{0 . 0 1 0}$ & Berpengaruh positif \\
DAR -> ROA & -0.182 & -0.184 & 0.034 & 5.294 & $\mathbf{0 . 0 0 0}$ & Berpengaruh negatif \\
DAR -> ROE & -0.030 & -0.033 & 0.054 & 0.554 & $\mathbf{0 . 2 9 0}$ & Tidak berpengaruh \\
AG -> ROE & 0.268 & 0.270 & 0.036 & 7.370 & $\mathbf{0 . 0 0 0}$ & Berpengaruh positif \\
AG -> PBV & 0.058 & 0.060 & 0.030 & 1.909 & $\mathbf{0 . 0 2 8}$ & Berpengaruh positif \\
ROE -> RS & 0.137 & 0.134 & 0.035 & 3.952 & $\mathbf{0 . 0 0 0}$ & Berpengaruh positif \\
\hline PBV -> RS & 0.435 & 0.409 & 0.145 & 3.006 & $\mathbf{0 . 0 0 1}$ & Berpengaruh positif \\
\hline
\end{tabular}

Analisis hasil pengujian pengaruh hubungan langsung antar variabel di group I (DAR $<50 \%$ ) pada tabel 4.1 adalah: 1 . Variabel DAR berpengaruh positif signifikan terhadap $\mathrm{AG} ; 2$. DAR berpengaruh negatif terhadap ROA; 3. DAR tidak mempengaruhi ROE; 4. AG berpengaruh positif terhadap ROE ; 5 . AG berpengaruh positif terhadap PBV; 6 . ROE berpengaruh positif terhadap RS, dan ; 7. PBV berpengaruh positif signifikan terhadap RS

Hasil di group I menunjukan bahwa kenaikan hutang (DAR) akan meningkatkan pertumbuhan aset (AG). Hasil berikutnya penambahan hutang (leverage) justru akan menurunkan profitabilitas (ROA), meskipun tidak mempengaruhi deviden (ROE). Hal ini dibuktikan dari nilai t statistic 0,554 dan nilai signifikansi 0,290 lebih besar dari 0,05 menunjukan utang (DAR) tidak berpengaruh terhadap (ROE). Hasil selanjutnya, kenaikan pertumbuhan aset (AG) akan meningkatkan deviden (ROE) dan harga sahamnya (PBV). Sedangkan kenaikan ROE dan PBV tersebut berpengaruh signifikan terhadap peningkatan return saham (RS).

Hutang merupakan sumber modal selain ekuitas dan laba ditahan untuk menambah aset perusahaan. Hasil peneltian menunjukan bahwa pemacu utama kenaikan deviden dan harga saham adalah dari kenaikan asset growth. Hasil ini mengindikasikan bahwa kenaikan aset perusahaan bukan semata-mata pengaruh dari penambahan hutang, melainkan ada sumber dana lain terhadap kenaikan aktiva misalnya dari suntikan modal ekuitas, hibah, maupun dari penggunaan laba ditahan. Masuknya penggunaan sumber dana lain tersebut dapat ditengarai dari pengujian hubungan langsung antara hutang (DAR) terhadap ROA yang menunjukan arah negatif dan DAR terhadap ROE hasilnya tidak berpengaruh.

Hasil penelitian ini menunjukan skema menambah hutang untuk menumbuhkan aset (ekspansi usaha) agar laba meningkat, namun hal itu belum sebagai pilihan terbaik. Penambahan hutang potensi keuntungan bagi pemegang obligasi maupun pihak ketiga (kreditur). Akan tetapi, kenaikan hutang berdampak pada menurunya profitabilitas dan meningkatkan resiko yang dapat mempengaruhi minat investor. Sedangkan bagi pemerintah menurunya profitabilitas (ROA) akan mengurangi jumlah setoran pajak. Hasil ini sejalan dengan temuan Singh, A. \& Hamid, J (1992) bahwa negara-negara berkembang lebih mengutamakan pendanaan dengan mengeluarkan ekuitas saham daripada mengakses sumber pinjaman dana dari pihak eksternal (hutang).

Tabel 4.2

Efek Tidak Langsung Spesifik

Mean, STDEV, T-Values, P-Values 
Merdeka Belajar dan Tantangan Ekonomi dalam Menyongsong Era Society 5.0

\begin{tabular}{|c|c|c|c|c|c|c|}
\hline Group I (DAR <50\%) & $\begin{array}{l}\text { Sampel } \\
\text { Asli(0) }\end{array}$ & $\begin{array}{l}\text { Rata-rata } \\
\text { sampel (M) }\end{array}$ & $\begin{array}{l}\text { Standarasi } \\
\text { (STDEV) }\end{array}$ & $\begin{array}{l}\text { T Statistik } \\
\text { (|O/STDEV|) }\end{array}$ & $\begin{array}{l}\mathbf{P} \\
\text { Values }\end{array}$ & $\begin{array}{l}\text { Analisis hasil } \\
\text { olahdatamSEM-Smart } \\
\text { PLS (Alfa 5\%) }\end{array}$ \\
\hline DAR $->$ AG $->$ ROE & .017 & .018 & .008 & .235 & .013 & Mediasi positif \\
\hline DAR $->A G ~->$ PBV & .004 & .004 & .003 & .377 & .085 & Tidak memediasi \\
\hline DAR -> ROE -> RS & 0.004 & 0.005 & .008 & .549 & .292 & Tidak memediasi \\
\hline$A G->R O E->R S$ & .037 & .037 & .011 & .217 & .001 & Mediasi positif \\
\hline AG $->$ PBV $->$ RS & .025 & .024 & .015 & .703 & .045 & Mediasi positif \\
\hline DAR->AG->ROE->RS & .002 & .002 & .001 & .916 & .028 & Mediasi positif \\
\hline DAR->AG->PBV-> RS & .002 & .002 & .001 & .240 & 0.108 & Tidak memediasi \\
\hline
\end{tabular}

Dari pengujian tidak langsung di group I (DAR $<50 \%)$ diketahui hubungan DAR $>$ AG -> ROE hasilnya pertumbuhan aset (AG) dapat memediasi positif. Hasil ini menunjukan bahwa kenaikan hutang perusahaan digroup I akan meningkatkan deviden apabila kenaikan hutang tersebut digunakan untuk menambah aset. Hal ini dapat dibuktikan dengan nilai statistik 2,235 dan nilai signifikansi 0,013 lebih kecil dari 0,05 sehingga hipotesis diterima.Kemudian pada pengujian DAR $>$ ROE $>>$ RS, hasilnya ROE tidak memediasi. Hal ini menunjukan jika kenaikan hutang tanpa disertai pertumbuhan aset maka keuntungan bersihnya (deviden) tidak akan berubah signifikan.

Berikutnya pengujian hubungan tak langsung DAR $\rightarrow$ AG $\rightarrow$ PBV, hasilnya AG tidak memediasi pengaruh DAR terhadap harga saham (PBV). Sedangkan pada pengujian DAR $>$ AG $\rightarrow$ ROE $>$ RS, hasilnya memediasi positif signifikan. Hasil ini menunjukan kenaikan leverage (hutang) yang digunakan untuk menambah pertumbuhan aset akan meningkatkan laba bersih (deviden). Sedangkan dari pengujian DAR $>$ AG $>$ PBV $>$ RS, hasilnya tidak memediasi (hipotesis ditolak). Hal ini menunjukan bahwa kenaikan hutang dengan mediasi pertumbuhan aset tidak berpengaruh terhadap harga saham.

Dari hasil analisis pengujian langsung dan tak langsung di group I dapat disimpulkanbahwa kenaikan hutang (leverage) tidak signifikan dalam meningkatkan harga saham (market value), tetapi berpengaruh signifikan terhadap peningkatan laba bersih (deviden) dan return saham dengan syarat bila kenaikan hutang tersebut digunakan untuk menambah aset. Artinya pada perusahaan dengan DAR $<50 \%$ jika kenaikan hutang untuk menambah pertumbuhan aset (ekspansi), maka laba bersih (deviden) dan return saham akan meningkat.

Dengan demikian pada perusahaan group I yang memiliki DAR $<50 \%$ bahwa penambahan leverage (hutang) apabila diikuti dengan kenaikan pertumbuhan aset akan meningkatkan laba bersih (deviden), sehingga keuntungan pemegang saham semakin besar. Hasil ini sesuai teori trade off yang menjelaskan bahwa perusahaan dapat melakukan perubahan-perubahan struktur modal hingga mencapai titik optimal dalam meningkatkan profitabilitas. Hasil ini juga sejalan dengan teori MM dimana perusahaan dapat melakukan perubahan stuktur modal (leverage) untuk meningkatkan profitabilitas (laba).

\section{Mengevaluasi Nilai $\mathbf{R}^{\mathbf{2}}$}

Menguji kelayakan model menggunakan nilai $\mathbf{R}^{\mathbf{2}}$ seperti pada tabel berikut ini.

Tabel 4.3

R SquareMean, STDEV, T-Values, P-Values

\begin{tabular}{llllll}
\hline DAR $<$ 50\% & SampelAsli $(\mathbf{O})$ & $\begin{array}{l}\text { Rata- } \\
\text { rataSampel } \\
\text { (M) }\end{array}$ & $\begin{array}{l}\text { StandarDeviasi } \\
(\text { STDEV) }\end{array}$ & $\begin{array}{l}\text { T Statistik } \\
(\mid \text { O/STDEV } \mid)\end{array}$ & $\begin{array}{l}\text { P } \\
\text { Values }\end{array}$ \\
AG & 0.004 & 0.005 & 0.004 & 1.102 & $\mathbf{0 . 1 3 5}$ \\
PBV & 0.003 & 0.005 & 0.004 & 0.838 & $\mathbf{0 . 2 0 1}$
\end{tabular}




\begin{tabular}{llllll} 
ROA & 0.033 & 0.035 & 0.013 & 2.570 & $\mathbf{0 . 0 0 5}$ \\
ROE & 0.072 & 0.077 & 0.020 & 3.577 & $\mathbf{0 . 0 0 0}$ \\
RS & 0.254 & 0.250 & 0.126 & 2.009 & $\mathbf{0 . 0 2 3}$ \\
\hline
\end{tabular}

Variabel asset growth memiliki nilai R square 0,004 yang menunjukan bahwa DAR mampu mempengaruhi asset growth sebesar 0,4\%. Nilai R square PBV yaitu 0,003 artinya DAR dan asset growth mempengaruhi PBV sebesar 0,3\%. Nilai R square ROA 0,033 artinya DAR mampu mempengaruhi ROA 3,3\%. Nilai R square ROE yaitu 0,072 artinya DAR dan asset growth mempengaruhi ROE sebesar 7,2\%. Nilai R square return saham 0,254 artinya DAR, AG, ROE, dan PBV mampu mempengaruhi Return Saham (RS) sebesar 25,4\%.

\section{Validasi Model Struktural dengan Goodness of Fit Index}

Tujuan melakukan pengujian Goodness of Fit Index (GoF) adalah untuk memvalidasi model struktural secara keseluruhan atau performa gabungan antara model pengukuran (outer model) dan model struktural (inner model) yang diperoleh melalui perhitungan:

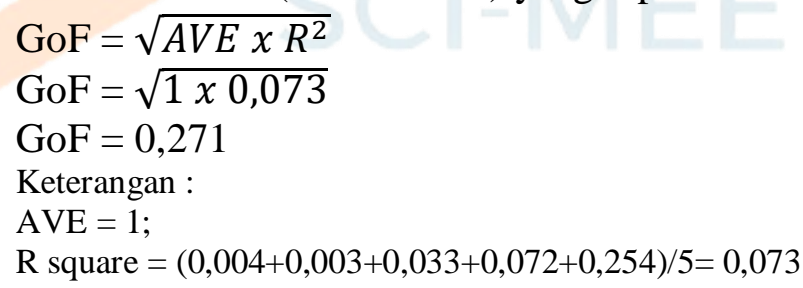

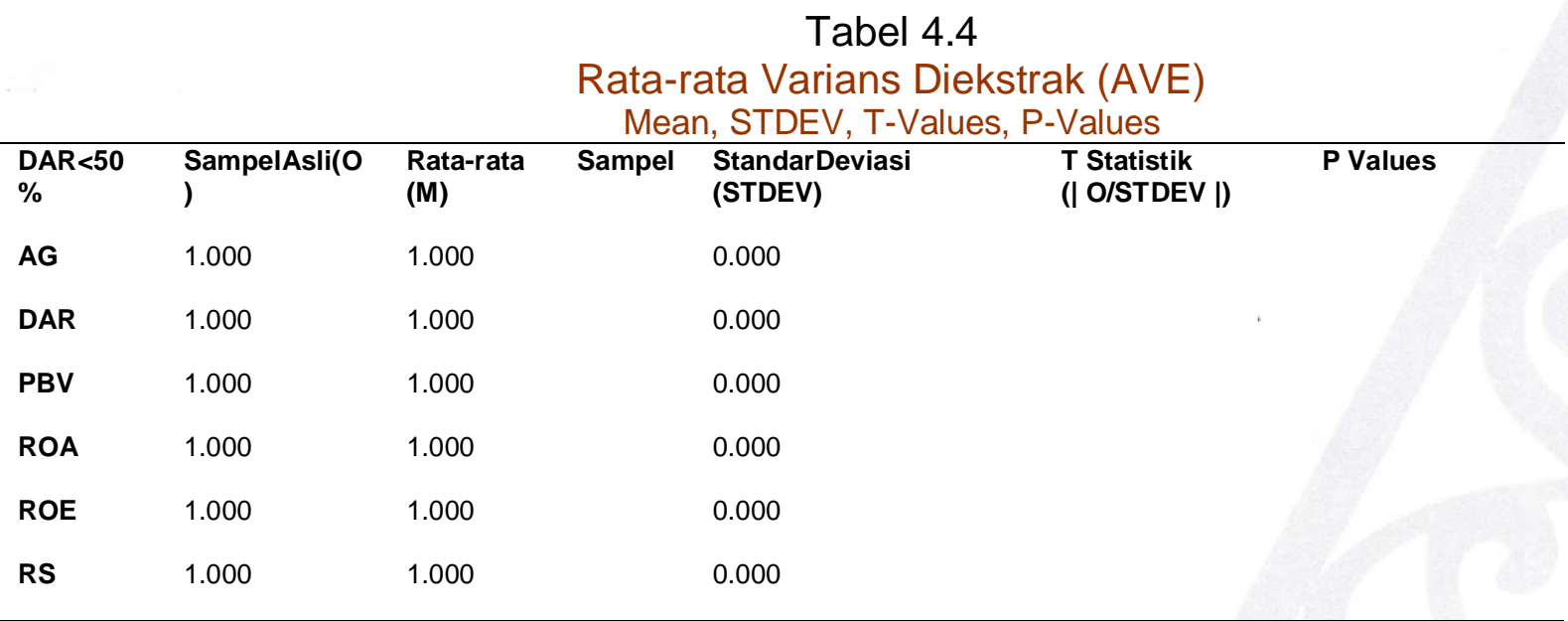

Hasil perhitungan Goodness of Fit Index (GoF) menunjukkan nilai 0,271. Berdasarkan hasil tersebut maka dapat disimpulkan bahwa performa gabungan antara model pengukuran (outer model) dan model struktural (inner model) secara keseluruhan adalah baik karena nilai Goodness of Fit Index (GoF) lebih dari 0,25 (Skalamoderat).

\section{Pengujian Predictive Relevance $\left(\mathbf{Q}^{2}\right)$}

Tujuan melakukan pengujian predictive relevance $\left(\mathrm{Q}^{2}\right)$ adalah untuk memvalidasi model. Hasil perhitungan $\mathrm{Q}^{2}$ adalah sebagai berikut:

$$
\begin{aligned}
& \mathrm{Q} 2=1-\left[\left(1-\mathrm{R}_{1}^{2}\right)\left(1-\mathrm{R}_{1}^{2}\right)\left(1-\mathrm{R}_{1}^{2}\right)\left(1-\mathrm{R}_{1}^{2}\right)\left(1-\mathrm{R}_{1}^{2}\right)\right] \\
& \mathrm{Q} 2=1-[(1-0,004)(1-0,003)(1-0,03)(1-0,072)(1-0,254)] \\
& \mathrm{Q} 2=1-0,665 \\
& \mathrm{Q} 2=0,335
\end{aligned}
$$

Berdasarkan hasil perhitungan predictive relevance $(\mathrm{Q} 2)$ diatas, menunjukkan nilai 0,335. Dalam model penelitian ini, variabel laten endogen memiliki nilai predictive relevance 
Merdeka Belajar dan Tantangan Ekonomi dalam Menyongsong Era Society 5.0 $\left(\mathrm{Q}^{2}\right)$ yang lebih besar dari 0 (nol) sehingga variabel laten eksogen sesuai sebagai variable penjelas yang mampu memprediksi variabel endogennya yaitu kinerja atau dengan kata lain membuktikan bahwa model ini dinilai memiliki predictive relevance yang baik.

\section{Hasil Deskriptif DAR $\geq \mathbf{5 0 \%}$}

Gambar 4.1 Hasil Pengujian KoefisienJalur (Path Coefficient)
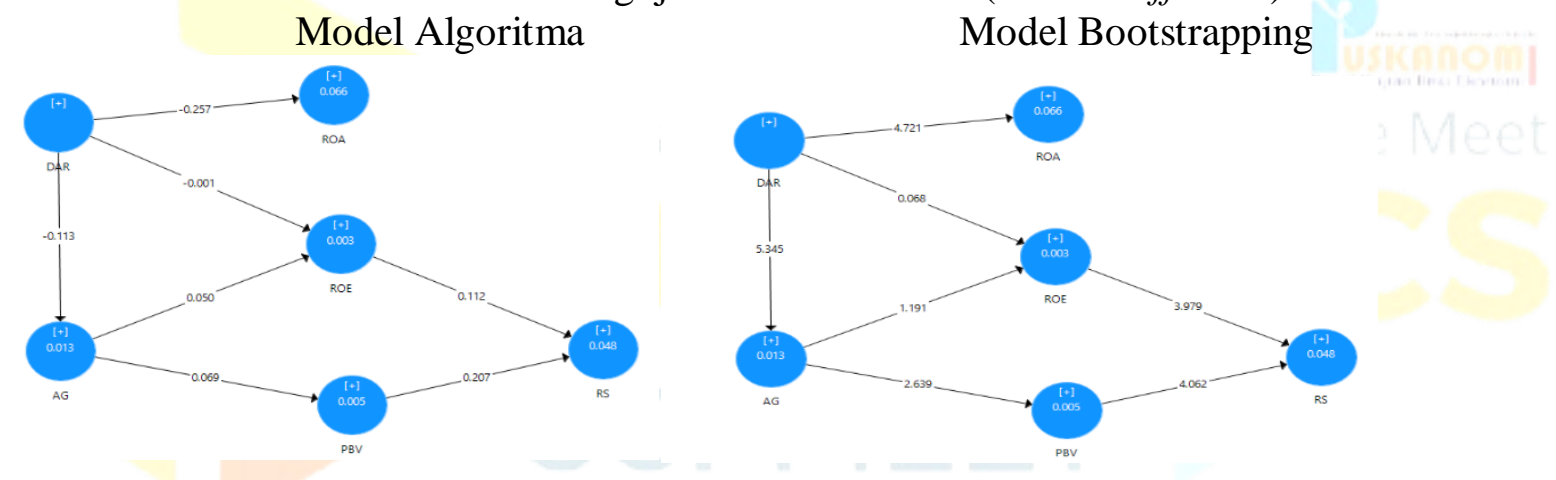

Model algoritma pada gambar 4.1 adalah model SEM dimana yang ditampilkan pada model adalah nilai koefisien SEM. Misalnya -0,113 pada DAR terhadap Asset Growth yang merupakan nilai koefisien SEM. Sedangkan model algoritma pada gambar 4.2 adalah model SEM dimana yang ditampilkan pada model adalah nilai T Statistik SEM. Misalnya 5,345 pada DAR terhadap Asset Growth yang merupakan nilai t statistik SEM.

Tabel 4.5

KoefisienJalur

Mean, STDEV, T-Values, P-Values

\begin{tabular}{lllllll}
\hline DAR $\geq 50 \%$ & $\begin{array}{l}\text { Sampel } \\
\text { asli(O) }\end{array}$ & $\begin{array}{l}\text { Rata-rata } \\
\text { Sampel(M) }\end{array}$ & $\begin{array}{l}\text { Standar } \\
\text { Deviasi } \\
\text { (STDEV) }\end{array}$ & $\begin{array}{l}\text { TStatistik } \\
(|\mathbf{O} / \mathbf{S T D E V}|)\end{array}$ & $\begin{array}{l}\text { P } \\
\text { Values }\end{array}$ & $\begin{array}{l}\text { Analisa hasil group II } \\
\text { DAR } \geq 50 \%\end{array}$ \\
AR $->$ AG & 0.113 & 0.114 & .021 & .345 & 0.000 & Berpengaruh negatif \\
AR>ROA & 0.257 & 0.262 & .054 & .721 & 0.000 & Berpengaruh negatif \\
AR> ROE & 0.001 & 0.001 & .020 & .068 & $\mathbf{0 . 4 7 3}$ & Tidak berpengaruh \\
G -> ROE & .050 & .052 & .042 & .191 & $\mathbf{0 . 1 1 7}$ & Tidak berpengaruh \\
G -> PBV & .069 & .071 & .026 & .639 & 0.004 & Berpengaruh positif \\
OE -> RS & 0.112 & .112 & .028 & .979 & 0.000 & Berpengaruh positif \\
BV -> RS & 0.207 & .206 & .051 & .062 & 0.000 & Berpengaruh positif \\
\hline
\end{tabular}

Informasi pada tabel 4.5 merupakan hasil pengujian dan analisis data SEM-Smart PLS mengenai pengaruh hubungan langsung (direct effek) dan tak langsung (indirect effek) antar variabel. Berdasarkan hasil pengujian hubungan langsung antar variabel digroup II (DAR $\geq$ $50 \%$ ) menunjukan bahwa setiap ada kenaikan hutang (DAR) akan menurunkan pertumbuhan aset (AG) dan profitabilitas (ROA) dan sebaliknya. Akan tetapi perubahan hutang tersebut (DAR) tidak mempengaruhi deviden (ROE) yang ditunjukan dari nilai t statistik 0,068 dan signifikansi 0,473, dengan nilai signifikansi > 0,05 (hipotesis ditolak). Pengujian berikutnya Pertumbuhan aset (AG) hasilnya tidak mempengaruhi deviden (hipotesis ditolak), tetapi Pertumbuhan Aset mempengaruhi kenaikan harga saham (PBV), dan kenaikan PBV mempengaruhi peningkatan return saham (RS).

Dengan demikian hasil pengujian hubungan langsung digroup II (DAR $\geq 50 \%$ ) dapat disimpulkan bahwa setiap ada kenaikan leverage (hutang) maka pertumbuhan aset menurun dan sebaliknya. Kenaikan pertumbuhan aset tidak mempengaruhi laba bersih (deviden), tetapi berpengaruh signifikan terhadap peningkatan harga saham sehingga meningkatkan return

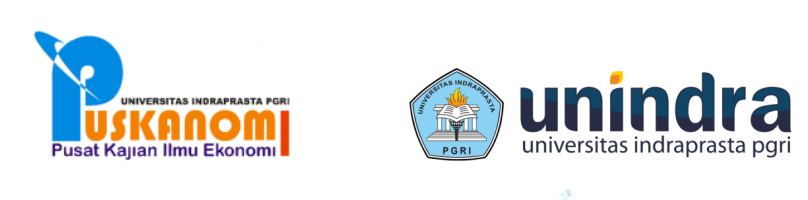


saham. Hasil ini memberikan isyarat bahwa peningkatan leverage (hutang) oleh perusahaan yang memiliki DAR $\geq 50 \%$ berpotensi tinggi meningkatkan harga saham (market value) secara signifikan tetapi tidak signifikan dalam meningkatkan profitabilitas (deviden). Hasil ini sesuai dengan teori trade off (2001) tentang struktur modal yang optimal dan sejalan dengan teori David Darian (1952) dengan pendekatan tradisional yang berpendapat bahwa penggunaan hutang dapat mempengaruhi nilai total perusahaan yang optimal.

Akan tetapi hasil ini kurang sejalan dengan teori Modigliani Miller (1958) yang berpandangan bahwa struktur modal tidak mempengaruhi nilai perusahaan. Kurang sejalanya dengan teori Modigliani Miller (MM) tersebut dapat dibuktikan dari pengaruh hubungan struktur modal (hutang) yang berdampak negatif terhadap pertumbuhan aset dan harga saham, meskipun perubahan tersebut tidak berdampak signifikan terhadap profitabilitas. Artinya pada perusahaan (emiten) yang memiliki DAR > 50\% jika masih meningkatkan leverage (hutang) akan berakibat pada menurunnya harga saham, sehingga pada kondisi inilah dampak yang kurang sejalan dengan teori MM.

Tabel 4.6

\begin{tabular}{|c|c|c|c|c|c|c|}
\hline \multirow[b]{2}{*}{ Group II DAR $\geq \mathbf{5 0 \%}$} & \multicolumn{5}{|c|}{$\begin{array}{l}\text { Efek Tidak Langsung Spesifik } \\
\text { Mean, STDEV, T-Values, P-Values }\end{array}$} & \multirow{3}{*}{$\begin{array}{l}\text { Analisis hasil olah } \\
\text { data group II DAR } \geq \\
50 \% \\
\text { Tidak memediasi }\end{array}$} \\
\hline & $\begin{array}{l}\text { Sampel } \\
\text { asli (0) }\end{array}$ & $\begin{array}{l}\text { Rata-rata } \\
\text { sampel (M) }\end{array}$ & $\begin{array}{l}\text { Standar } \\
\text { Deviasi } \\
\text { (STDEV) }\end{array}$ & $\begin{array}{l}\text { T Statistik } \\
\text { | O/STDEV |) }\end{array}$ & $\begin{array}{l}\mathbf{P} \\
\text { values }\end{array}$ & \\
\hline DAR $>$ AG $->$ ROE & 006 & 0.006 & .005 & .147 & 126 & \\
\hline DAR $->A G ~->$ PBV & 008 & 0.008 & .004 & .199 & 0.014 & Memediasi negatif \\
\hline DAR $->$ ROE $->$ RS & 000 & .000 & .002 & .063 & .475 & Tidak memediasi \\
\hline$A G->R O E->R S$ & 006 & .006 & 0.005 & .064 & 144 & Tidak memediasi \\
\hline$A G->P B V->R S$ & 014 & .015 & .006 & .205 & .014 & Memediasi positif \\
\hline DAR $->A G->R O E->R S$ & 001 & 0.001 & .001 & .038 & 150 & Tidak memediasi \\
\hline DAR $>A G$-> PBV-> RS & 0.002 & 0.002 & 0.001 & 1.912 & 0.028 & Memediasi negatif \\
\hline
\end{tabular}

Pada pengujian hubungan tidak langsung di group II (DAR >50\%): Pengaruh DAR->AG$>$ ROE, hasilnya pertumbuhan aset (AG) tidak memediasi, menunjukkan perubahan hutang (DAR) dengan intervening pertumbuhan aset (AG) tidak mempengaruhi deviden (ROE). Hal ini dibuktikan dari nilai statistik 1,147 dan signifikansi 0,126 lebih besar 0,05 sehingga hipotesis ditolak. Sedangkan pada uji pengaruh DAR->AG->PBV, hasilnya memediasi negatif, artinya kenaikan hutang (leverage) maka harga saham (PBV) akan menurun dengan variabel mediasi AG, dan sebaliknya jika hutang menurun maka harga saham meningkat yang dimediasi oleh AG. Hal ini terbukti dari nilai statistik 2,199 dan signifikansi 0,014<0,05 sehingga hipotesis diterima.

Pengujian berikutnya yaitu DAR->AG->ROE->RS hasilnya tidak memediasi, menunjukan perubahan hutang (DAR) melalui variabel intervening AG dan ROE tidak mempengaruhi return saham. Tetapi pada pengujian DAR $>\mathbf{A G}$-> PBV $\rightarrow>$ RS hasilnya memediasi dengan arah negatif yang dibuktikan dengan nilai statistik 1,912 dan nilai signifikansi 0,028 yang lebih besar dari 0,05 sehingga hipotesis diterima. Hasil ini menunjukan bahwa setiap kenaikan hutang (leverage) melalui variabel dimediasi AG dan ROEmaka return saham akan menurun. Dan sebaliknya jika hutangnya menurun maka retun saham meningkat yang dimediasi oleh peningkatan AG dan deviden (ROE).

Dari hasil pengujian langsung dan tidak langsung antar variabel pada group II (DAR $>50 \%$ ) dapat disimpulkan bahwa perubahan hutang (leverage) tidak berpengaruh terhadap deviden tetapi mempengaruhi harga saham melalui variabel mediasi AG. Jika hutang 
Merdeka Belajar dan Tantangan Ekonomi dalam Menyongsong Era Society 5.0

(leverage) meningkat maka Aset growth, deviden dan harga saham akan menurun, dan sebaliknya jika hutang menurun maka pertumbuhan aset dan harga saham meningkat sehingga ekspektasi terhadap return saham semakin besar. Hasil ini sesuai teori struktur modal yang mengungkapkan bila hutang semakin tinggi maka beban biaya modal, resiko likuiditas dan solvabilitas makin tinggi. Kondisi tersebut dapat menambah kekhawatiran pemilik modal atau menurunkan minat invetsor yang berdampak menurunya harga saham.

\section{Mengevaluasi Nilai $\mathbf{R}^{2}$}

Eavluasi nilai $\mathbf{R}^{2}$ dilakukan untuk menguji kelayakan model dengan hasil output berikut ini.

\section{Tabel 4.7}

\section{R Square}

Mean, STDEV, T-Values, P-Values

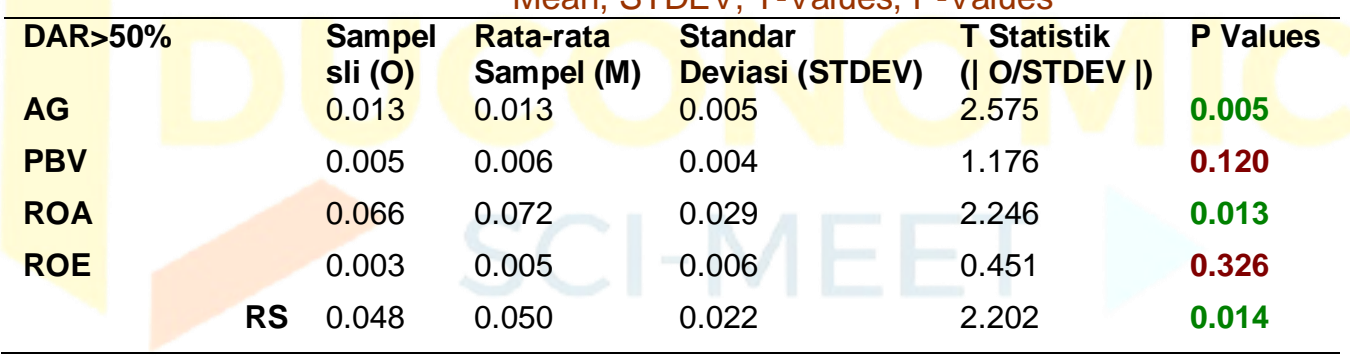

Variabel asset growth memiliki nilai R square yaitu 0,013 yang dapat diartikan bahwa DAR mampu mempengaruhi asset growth sebesar 1,3\%. Nilai nilai R square PBV 0,005 artinya DAR dan asset growth mempengaruhi PBV 0,5\%. Nilai R square ROA 0,066 artinya DAR mampu mempengaruhi ROA 6,6\%. Nilai $\mathrm{R}$ square ROE yaitu 0,003 artinya DAR dan asset growth mempengaruhi ROE sebesar $0,3 \%$. Nilai $\mathrm{R}$ squarereturn saham 0,048 artinya DAR, asset growth, ROE, dan PBV dapat mempengaruhi return saham sebesar 4,8\%.

\section{Validasi Model Strukturaldengan Goodness of Fit Index}

Tujuan pengujian Goodness of Fit Index (GoF) adalah untuk memvalidasi model struktural secara keseluruhan atauperforma gabungan antara model pengukuran (outer model) dan model struktural (inner model) yang didapat melalui perhitungan sebagai berikut:

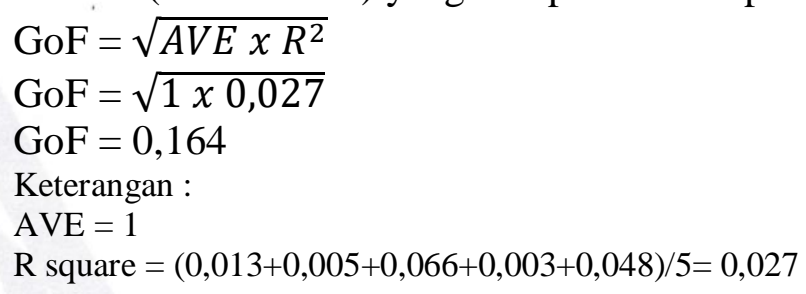

Tabel 4.8

Rata-rata Varians Diekstrak (AVE) Mean, STDEV, T-Values, P-Values

\begin{tabular}{|c|c|c|c|c|c|}
\hline DAR $>\mathbf{5 0 \%}$ & $\begin{array}{l}\text { Sampel } \\
\text { Asli (O) }\end{array}$ & Rata-rataSampel(M) & $\begin{array}{l}\text { Standar } \\
\text { Deviasi (STDEV) }\end{array}$ & $\begin{array}{l}\text { T Statistik } \\
\text { (|O/STDEV |) }\end{array}$ & P Values \\
\hline AG & 1.000 & 1.000 & 0.000 & & \\
\hline DAR & 1.000 & 1.000 & 0.000 & & \\
\hline PBV & 1.000 & 1.000 & 0.000 & & \\
\hline ROA & 1.000 & 1.000 & 0.000 & & \\
\hline ROE & 1.000 & 1.000 & 0.000 & & \\
\hline RS & 1.000 & 1.000 & 0.000 & & \\
\hline
\end{tabular}

Hasilperhitungan Goodness of Fit Index (GoF) menunjukkannilai 0,164. Berdasarkanhasiltersebutmakadapatdisimpulkanbahwaperformagabunganantara model pengukuran (outer model) dan model struktural (inner model) secarakeseluruhanadalahcukupbaikkarenanilai Goodness of Fit Index (GoF) kecildari 0,25 
(Skalamoderat)danlebihbesardari 0,1.

\section{Pengujian Predictive Relevance $\left(\mathbf{Q}^{2}\right)$}

Tujuan melakukan pengujian predictive relevance $\left(\mathrm{Q}^{2}\right)$ adalah untuk memvalidasi model. Hasil perhitungan $\mathrm{Q}^{2}$ adalah sebagai berikut:

$$
\begin{aligned}
& \mathrm{Q} 2=1-\left[\left(1-\mathrm{R}_{1}^{2}\right)\left(1-\mathrm{R}_{1}^{2}\right)\left(1-\mathrm{R}_{1}^{2}\right)\left(1-\mathrm{R}_{1}^{2}\right)\left(1-\mathrm{R}_{1}^{2}\right)\right] \\
& \mathrm{Q} 2=1-[(1-0,013)(1-0,005)(1-0,066)(1-0,003)(1-0,048)] \\
& \mathrm{Q} 2=1-0,871 \\
& \mathrm{Q} 2=0,129
\end{aligned}
$$

Berdasarkan hasil perhitungan predictive relevance $(\mathrm{Q} 2)$ diatas, menunjukkan nilai 0,129 . Dalam model penelitian ini, variabel laten endogen memiliki nilai predictive relevance $\left(\mathrm{Q}^{2}\right)$ yang lebih besar dari 0 (nol) sehingga variabel laten eksogen sesuai sebagai variable penjelas yang mampu memprediksi variabel endogennya yaitu kinerja atau dengan kata lain membuktikan bahwa model ini dinilai memiliki predictive relevance yang baik.

\section{SIMPULAN}

Hasil digroup I (DAR $<50 \%)$ : Hutang (DAR) berpengaruh positif terhadap Asset growth (AG) dan DAR berpengaruh negatif terhadap profitabilitas (ROA), tetapi DAR tidak mempengaruhi deviden (ROE);Kemudian pertumbuhan aset (AG) berpengaruh positif terhadap deviden (ROE) dan harga saham (PBV). Pada hubungan tak langsung: AG memediasi positif pengaruh DAR terhadap ROE dan Return Saham (RS); tetapi AG tidak memediasi pengaruh DAR terhadap PBV dan RS. Simpulan hasil group I adalah bahwa kenaikan hutang (leverage) akan meningkatkan asset growth dan deviden secara signifikan. Kemudian bagi perusahaan yang memiliki pertumbuhan aset tanpa menaikan hutang cenderung akan menghasilkan kenaikan deviden dan peningkatan harga saham.

Hasil digroup II (DAR $\geq 50 \%$ ): DAR berpengaruh negatif terhadap AG dan ROA, tetapi DAR tidak mempengaruhi ROE; Kemudian AG tidak mempengaruhi ROE, tetapi AG berpengaruh positif terhadap PBV. Pada pengujian tak langsung AG memediasi negatif pengaruh DAR terhadap ROE dan RS; tetapi AG memediasi positif DAR terhadap PBV dan RS. Simpulan hasil group II adalah bahwa kenaikan hutang (leverage) akan menurunkan aset growth dan profitabilitas dan sebaliknya, tetapi tidak berdampak pada laba bersih (deviden). Kemudian bagi perusahaan yang mampu menurunkan hutang dan atau meningkatkan asset growth maka harga saham (market share) cenderung meningkat.

Hasil penelitian ini juga memberikan indikasi bahwa tidak satupun analisis faktor fundamental yang mampu menjamin kepastian kenaikan laba bersih (deviden) dan harga sahamnya secara empiris pada setiap perusahaan, tetapi hasil ini menemukan bukti efektifitas struktur modal yang optimal dan pengaruhnya terhadap profitabilitas dan harga saham. Kesimpulan akhir dari kedua model pengujian ini adalah bahwa perusahaan yang memiliki hutang rendah dan mengalami pertumbuhan aset cenderung akan menghasilkan peningkatan deviden dan harga sahamnya naik semakin tinggi.

\section{SARAN}

Evaluasi hutang (struktur modal) yang optimal penting untuk meningkatkan performa finansial. Emiten dengan DAR $<50 \%$ dapat mengambil pinjaman (hutang) untuk menambah aset (ekspansi usaha) agar laba bersihnya meningkat, namun jika menghendaki harga saham 


\section{0}

Merdeka Belajar dan Tantangan Ekonomi dalam Menyongsong Era Society 5.0 juga naik maka perusahaan harus mampu meningkatkan aset tanpa menambah hutang. Sedangkan emiten dengan DAR $>50 \%$ sebaiknya bisa menumbuhkan aset agar laba bersih makin tinggi, namun jika menghendaki harga saham juga naik maka harus bisa menumbuhkan aset dan atau menurunkan hutangnya (leverage).

Pelaku pasar modal penting perhatikan rasio hutang dan aset perusahaan, mengingat variabel ini signifikan dalam memprediksi kenaikan laba bersih dan harga saham. Penelitian ini mencakup populasi dan sampel dari seluruh sektor usaha dengan model cukup kompleks sehingga deskripsinya terbatas. Penelitian selanjutnya dapat memfokuskan pada sektor tertentu atau studi empiris agar analisisnya lebih lengkap, terperinci dan mendalam.

Penutup merupakan simpulan dari hasil penelitian yang telah dilaksanakan dan merupakan jawaban dari rumusan masalah. Simpulan diselaraskan dengan rumusan masalah dan tujuan penelitian. Dalam hal simpulan lebih dari satu, maka dituliskan menggunakan penomoran angka dan bukan menggunakan bullet. Dalam bagian penutup ini juga dapat ditambahkan prospek pengembangan dari hasil penelitian dan aplikasi lebih jauh yang menjadi prospek kajian berikutnya.

\section{DAFTAR PUSTAKA}

Azis dan Hartono, 2017. Pengaruh Good Governance, Struktur Modal, DanLeverage Terhadap Kinerja Keuangan Perusahaan Pada Sektor Pertambangan Yang Terdaftar Di BEI 2011-2015. Jurnal Ilmu Manajemen Vol.5 No.3.Universitas Negeri Surabaya.

Brigham dan Ehrhardt. 2005. Financial Management Theory And Practice, Eleventh Edition. Ohio: South Western Cengage Learning.

BEI Catat Transaksi Harian Rp 2002 triliun https://investor.id/market andcorporate/

Christiawan, Jogi dan J Tarigan. 2007. Kepemilikan Manajeral: Kebijakan Hutang, Kinerja dan Nilai Perusahaan. Jurnal Akuntansi dan Keuangan, Vol. 9 No.1. Hal. 1-8. Surabaya: Universitas Kristen Petra.

Durand, D., 1989, Afterthoughts on a Controversy with MM, Plus New Thoughts on Growth and The Cost of Capital. Financial Management, Summer.

Fakhrudin, Hendy. M., 2008. Istilah Pasar Modal A-Z. Elex Media Komputindo, Jakarta.

Gitman, Lawrence J. 2006. Principles of Manajerial Finance. International Edition, 10 th edition. Boston: Pearson Education.

Ghozali, I. dan H. Latan. (2012). Partial Least Squares. Badan Penerbit: Universitas Diponegoro, Semarang.

Ghozali, Imam. (2016). Aplikasi Analisis Multivariate dengan Program SPSS. (Edisi Ke 4). Badan Penerbit: Universitas Diponegoro, Semarang.

Harmono. 2009. Manajemen Keuangan Berbasis Balanced Scorecard (Pendekatan Teori, Kasus, dan Riset Bisnis). Jakarta: Bumi Aksara.

Hamid, J.,dan Singh A.(1992). Corporate Financial Structure In developing Countries, International Financial Corporation. Technical Paper, 1-110.

Hair, J. F., Ringle, C.M., dan Sarstedt, M.(2013). Editorial Partial Least Square Structural Equation Modeling: Rigorous Applications, Better Results and Higher Acceptance. ELSEVIER, 1- 12.

Huda, Nurul dan Nasution, M. Edwin, 2005. Investasi pada pasar modal syari'ah. Kencana Prenada Media, Jakarta.

Layanan data BEI, https://www.idx.co.id/produk/

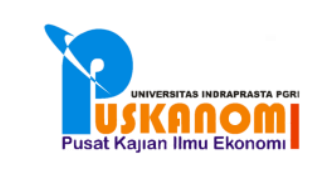


Matar dan Eneizan, 2018. Determinants of Financial Performance in the Industrial Firms: Evidence from Jordan. Asian Journal of Agricultural Extension, Economics \& Sociology 22(1): 1-10, 2018; AJAEES.37476 ISSN: 2320-7027. Jadara University. Jordan.

Modigliani, franco and Miller,Merton H.,"The Cost of Capital, Corporation Finance and Theory of Investment". The American Economic Review. Vol. 48, No. 3 (Jun., 1958), pp. 261-297 (37 pages).https://www.jstor.org/stable/1809766

Modigliani, F., dan Miller, M.H., 1963, Corporate Income Taxes Cost of Capital. American Economic Review, June, Vol.

92

Myers, S.C.(1984). The capital Structure Puzzle. Journal of Finance, July 39:3. P 75-

Myers N.S \& Maljuf, 2001. Corporate Finance And Investment Decision When Firm Have Information That Investors Do Not Have. NbeR Working Paper, No. W1396. Company/

Panduan Go Public. pdf. https://www.idx.co.id/Portals/0/Static Data/Information/ For

Rajkumar. P., 2014. Impact of financial Leverage On Financial Performance: Special reference To John Keells Holdings PLC In Sri Lanka. Scientific Researh Journal (SCIRJ) Volume II, Issue II, february 2014; 15 ISSN 2201-2796.

Raisa Fitri, 2017. Pengaruh Kebijakan Dividen, Leverage Perusahaan Dan Profitabilitas Terhadap Return Saham (Studi Pada Perusahaan Sub Sektor Makanan Dan Minuman Yang Terdaftar Di BEI). Jibeka Volume 11 Nomor 2 Februari 2017 : 32 - 37

Ringle, C. M., Wende, S., dan Becker, J.-M. 2015. "Smart PLS 3." Boenningstedt: Smart PLS GmbH, http://www.smartpls.com.

Saham-saham ini naik lebih dari 100 sepanjang 2020 berjalan bagaimanakinerjanya? https://investasi.kontan.co.id/news/

Sartono, Agus 2008. Manajemen Keuangan Teori, dan Aplikasi. BPFE, Yogyakarta.

Setiadewi Dan Purbawangsa, 2015. Pengaruh Ukuran Perusahaan Dan Leverage Terhadap Profitabilitas Dan Nilai Perusahaan.

Setyawan \& Syaftina (2013), Penilaian Kinerja Keuangan Pada Emiten Lq-45 Periode 2007 - 2011 Di Bursa Efek Indonesia. Jurnal Akuntansi/Volume XVII, No. 01, Januari 2013: 84-100 Bandung.

Sugiyono, (2010). Metode Penelitian Kuantitatif, kualitatif dan R\&D. Alfabeta :

Sugiyono. 2016. Statistika untuk Penulisan, cetakan ke-27. Alfabeta. Bandung: .

Schutte, Maarten (2018) The effect of leverage on financial performance: An analysis of European listed firms.http://purl.utwente.nl/essays/77006

Tim Riset Bisnis Indonesia "Inilah 100 Emiten Tumbuh Kinclong 2019 Versi Bisnis Indonesia ", https://market.bisnis.com/read/20191028/7/1163956/

Wasfi A.Al Salamat dan Haneen H.H Mustafa, 2016. The Impact of Capital Structure on Stock Return: Empirical Evidence Amman Stock Exchange. International Journal of Business and Social Science Vol. 7, No. 9; September 2016. P183

Wold, H.(2013). Partial Least Square. In G. A. Marcoulides, Modern Methods For Business Research (P. 295). New York: Psychology Press. 